\title{
Combining rainfall data from rain gauges and TRMM in hydrological modelling of Laotian data-sparse basins
}

\author{
Xing Liu ${ }^{1}$ Fa Ming Liu ${ }^{2}$ Xiao Xia Wang ${ }^{1}$ Xiao Dong $\mathrm{Li}^{1} \cdot$ Yu Yan Fan ${ }^{1}$. \\ Shi Xiang Cai ${ }^{1} \cdot$ Tian Qi Ao ${ }^{1}$
}

Received: 5 February 2015/Accepted: 25 August 2015/Published online: 14 September 2015

(C) The Author(s) 2015. This article is published with open access at Springerlink.com

\begin{abstract}
At present, prediction of streamflow simulation in data-sparse basins of the South East Asia is a challenging task due to the absence of reliable ground-based rainfall information, while satellite-based rainfall estimates are immensely useful to improve our understanding of spatiotemporal variation of rainfall, particularly for data-sparse basins. In this study the TRMM 3B42 V7 and its bias-corrected data were, respectively, used to drive a physically based distributed hydrological model BTOPMC to perform daily streamflow simulations in Nam Khan River and Nam Like River basins during the years from 2000 to 2004 so as to investigate the potential use of the TRMM in complementing rain gauge data in hydrological modelling of data-sparse basins. The results show that although larger difference exists in the high streamflow process and the low streamflow process, the daily simulations fed with TRMM precipitation data could basically reflect the daily streamflow processes at the four stations and determine the time to peak. Furthermore, the calibrated parameters in the Nam Khan River basin are more suitable than that in the Nam Like River basin. By comparing the two precipitation data, it indicates that the integration of TRMM precipitation data and rain gauge data have a promising prospect on the hydrological process simulation in data-sparse basin.
\end{abstract}

Shi Xiang Cai

caishixiang@scu.edu.cn

Xing Liu

liux_1986@126.com

1 State Key Laboratory of Hydraulics and Mountain River Engineering, College of Water Resource and Hydropower, Sichuan University, Chengdu 610065, China

2 China Railway Eryuan Engineering Group Co., Ltd, Chengdu 610031, China
Keywords TRMM satellite precipitation - Distributed hydrological model - Laotian data-sparse basins .

Streamflow simulation

\section{Introduction}

Precipitation is one of the most important factors in the process of hydrological cycle. As basic input data for hydrological model simulations, the quality of Precipitation data exerts a tremendous influence upon the reliability of simulation results (Sorooshian et al. 2005; Meng et al. 2014). Moreover, with showing a non-normal distribution feature (Liu et al. 2011), precipitation remains one of many hydrographical factors which are difficult to be observed and estimated precisely (Yong et al. 2010). Currently, Precipitation estimates are mainly derived from two sources, i.e., rain gauge station observations and ground radar measurements. Rain gauge, though as a direct precipitation measuring instrument which is technologically mature and widely used, cannot reflect the spatial variation of rainfall effectively due to the distribution of rainfall stations and the very limited effective radius of point measurements (Collischonn et al. 2008; Jia et al. 2011). In comparison with rain gauge, ground radar system can provide the instantaneous spatial distribution of precipitation over the basin indirectly and thus help to offset the bias of rain gauge observations partly. But, because of its problem of limited coverage area, high costs of establishing and maintaining infrastructure, etc., there is no perfect radar network of many regions ( $\mathrm{Gu}$ et al. 2010). It still cannot meet the requirements of study carried out on large-scale basins. These drawbacks of conventionally obtained rainfall data impose a remarkable limitation on the application of distributed hydrological model. Recently, satellite

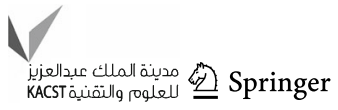


precipitation products such as TRMM (Huffman et al. 2007), CMORPH (Joyce et al. 2004), PERSIANN (Sorooshian et al. 2000) have emerged as a preferable alternative or supplement to conventional precipitation observations (Sawunyama and Hughes 2008; Yong et al. 2012) due to their high spatial-temporal resolution and availability over vast ungauged regions and hence improved the study and application of distributed hydrological model in many fields immensely.

Hydrological study in data-sparse and ungauged basin has been a hot and difficult issue. Restricted by disadvantageous strategic status, climate and traffic problems in regional economic development and water security system, numerous data-sparse and ungauged basins are found in many remote parts of the world and particularly in developing countries. For the purpose of achieving major advances in the capacity to make reliable prediction in ungauged basin, The International Association of Hydrological Sciences (IAHS) recently launched an initiative, called the Decade on Predictions in Ungauged Basins (PUB). Sivapalan et al. (2003) presented three methods for predictions of data-sparse basin responses: (1) interpolation or extrapolation of response information from gauged to ungauged basins, (2) measurements by remote sensing (e.g. radar, satellites.), (3) application of process-based hydrological models to reduce the dependency on specific precipitation inputs. Thus, using the distributed hydrological model, which makes full use of satellite based hydro-meteorological data, becomes a feasible approach to solve PUB problem. The block-wise use of the TOPMODEL (Beven et al. 1995) with the Muskingum-Cunge routing method (Cunge 1969) model (BTOPMC) is a physically based distributed hydrological model based on subdividing the entire basin into sub-basins that consist of a number of grid cells (Takeuchi et al. 1999; Ao 2001; Ao et al. 2006). It has parsimonious model parameters, which can reduce parameter interaction and uncertainty and low requirement on inputs. BTOPMC was also successfully used to model Mekong River basins in Laos and Thailand of the South East Asia in previous studies (Hapuarachchi et al. 2004, 2007).

Obviously, for data-sparse and ungauged basins, using satellite rainfall products to drive distributed hydrological model is an ideal choice to tackle PUB problem. In this regard, the rainfall estimates from TRMM, particularly the TRMM Multi-satellite Precipitation Analysis (TMPA) type, have been used by a number of researchers (Su et al. 2008; Habib et al. 2009; Scheel et al. 2011). Current resolution of TRMM satellite rainfall product has reached $0.25 \times 0.25$, which is obviously too coarse for small-scale catchment. Hong et al. (2007) proposed a simple but practicable NRCS$\mathrm{CN}$ streamflow simulation method driven by TMPA products to simulate the quasi-global runoff; their research results indicate that simulation precision improves dramatically when the basin area is larger than $10,000 \mathrm{~km}^{2}$. Although their reports demonstrate the potential of TMPA products in runoff forecasting at large and even global scale, evaluation of satellite-based rainfall estimation error and its nonlinear influence on rainfall-runoff modelling uncertainty remains a major unaddressed hydrological concern. Mao (2008) studied the feasibility of using TRMM precipitation data to predict streamflow at upper catchment of Han Jiang River based on large-scale hydrological model LSHM; the research showed that simulation accuracy is somewhat relevant to the basin area, and furthermore, daily simulation still could be applied to water resource planning and management despite its relatively low simulation precision. Bitew and Gebremichael $(2011 \mathrm{a}, \mathrm{b})$ used four kinds of satellite rainfall products including TMPA, as inputs to SWAT for daily streamflow simulation in two meso-scale watersheds located in Africa, and discussed the effects of watershed area and different satellite rainfall products on streamflow simulation accuracy. It is of significant importance to do a comparative analysis job among TRMM rainfall products and other rainfall data such as rain gauge data, satellite products (Jiang et al. 2012; Kim et al. 2013) and reanalysis data (Artan et al. 2007; Li et al. 2013) to figure out their predictive capability in distributed hydrological model. Arias-Hidalgo et al. (2013) compared gauged precipitation with TRMM rainfall products at several time scales and came to the conclusion that TRMM rainfall products at monthly scale perform better than that at daily scale. Xue et al. (2013) explored the improvements of the latest 3B43V7 algorithm relative to 3B43V6 using the Coupled Routing and Excess Storage (CREST) hydrologic model; the results apparently show that the new algorithm 3B43V7 has much improved accuracy upon 3B43V6. There are two main different calibration approaches for simulating streamflow from satellite rainfall inputs: (1) calibrating the model with rain gauge measurements and validating the model with satellite rainfall; (2) calibrating the model with the satellite rainfall products (Artan et al. 2007; Stisen and Sandholt 2010). The studies of Jiang et al. (2012) and Kim et al. (2013) reveal that the second approach can better calibrate the parameters than the first approach. But, compared to calibrating hydrologic model with rain gauge data, calibrating the model with corresponding satellite rainfall data increases the performance of satellite streamflow simulation while decreasing the performance of satellite evapotranspiration simulation (Bitew and Gebremichael 2011a, b). Though being capable of reflecting the spatialtemporal heterogeneity of precipitation process over basin, TRMM rainfall products have relatively low precipitation accuracy. Since rain gauge measurements turn out to be fine on the contrary, it is supposed that complementing the TRMM satellite data with rain gauge measurements as an input to drive distributed hydrological model could enhance the runoff simulation precision. 
In this paper, Nam Khan River and Nam Like River basins, two data-sparse basins located in Laos which are in tropic zone, were chosen as the study area. The purpose of this study is to assess the hydrological potential of TRMM rainfall data and its derivatives driven as input into a hydrological model for streamflow simulation in Laotian data sparse basins. The raw and bias-corrected TRMM 3B42 V7 rainfall products were adopted to simulate rainfall-runoff process based on physical-based distributed hydrological model BTOPMC. The paper is organized as follows: Section 2 describes the study area, data and methodology. The results and discussions are presented in Sect. 3 and the conclusions are given in Sect. 4.

\section{Study region, data and methodology}

\section{Study region}

Nam Khan River basin (Fig. 1) is an important tributary of Mekong River. It flows through northern mountainous part of Laos with both sloping banks covered by forests and crops and feeds into Mekong River in Luang Prabang. The basin is located within $101^{\circ} 56^{\prime} \mathrm{E}-103^{\circ} 42^{\prime} \mathrm{E}$ and $19^{\circ} 22^{\prime} \mathrm{N}-$ $21^{\circ} 1^{\prime} \mathrm{N}$, with an area of about $7620 \mathrm{~km}^{2}$. There are two gauging stations, namely Ban Pak Bak station and Ban Mout station, with a drainage area of 5800 and $6100 \mathrm{~km}^{2}$, respectively.

Nam Like River (Fig. 1), as a branch of Nam Ngum River which is one of tributaries on the left bank of Mekong River, originates from Phou Khoun mountain located in Luang Prabang Province, flows through Vientiane Province, and finally joins the Nam Ngum River downstream the reservoir Nam Ngum. Nam Like River basin is located within $101^{\circ} 54^{\prime} \mathrm{E}-102^{\circ} 31^{\prime} \mathrm{E}$ and $18^{\circ} 29^{\prime} \mathrm{N}-$ $19^{\circ} 27^{\prime} \mathrm{N}$; two gauging stations are available in this basin with a drainage area of $374 \mathrm{~km}^{2}$ (Kasi station) and $5115 \mathrm{~km}^{2}$ (Hin Heup station), respectively. Annual mean rainfall of Nam Like River basin is around $1745 \mathrm{~mm}$, about $90 \%$ of which falls in rainy season (between May and October), with the rest $10 \%$ falling during the dry period (the rest of the year).

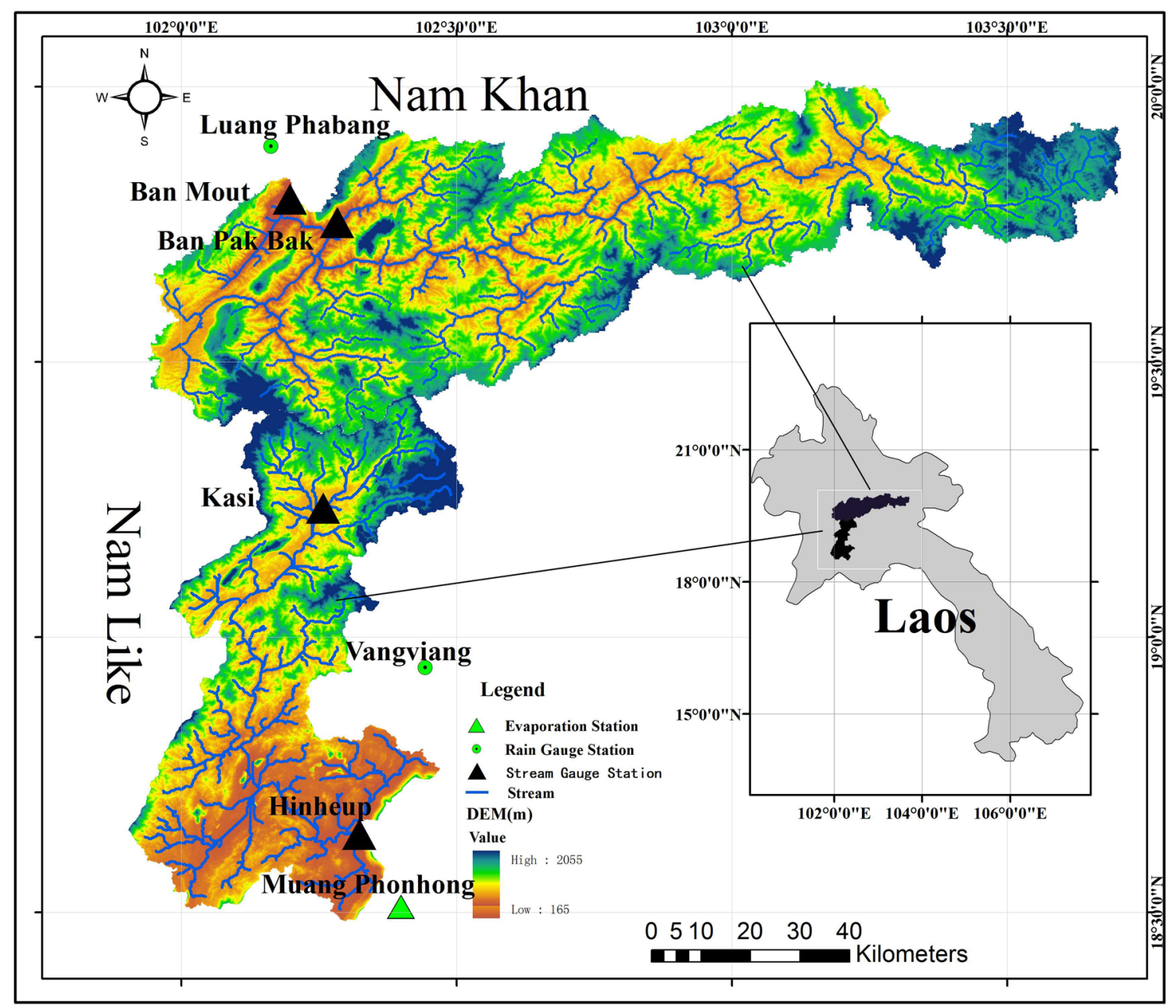

Fig. 1 Location of study area, river network and the distribution of stations 


\section{TRMM satellite products}

The Tropical Rainfall Measuring Mission, a joint US-Japan satellite mission, was launched in 1997 to monitor tropical and subtropical precipitation and to estimate its associated latent heating covering the latitude band $50^{\circ} \mathrm{N}-$ $50^{\circ} \mathrm{S}$. The TRMM satellite carries five rain-measuring instruments: Microwave Imager (TMI), the Visible Infrared Scanner (VIRS), The Lightning Imaging Sensor (LIS), the Clouds and Earth's Radiant Energy System (CERES) and the Precipitation Radar (PR) which is the first spaceborne precipitation radar. Among them, the CERES was out of service due to mechanical failure at present. So far, the TRMM rainfall products have updated to version 7 . Merged with other data from multiple satellites, products version 7 presents many new features such as larger coverage, higher spatial-temporal resolution, longer time series and being able to update real timely, which leads to a new wave of research about the application of TRMM rainfall products version 7 in meteorology, climatology, hydrology and other fields. TRMM rainfall products include several types, i.e., 3B40, 3B41, 3B42, etc., among which type $3 \mathrm{~B} 42$ data have the highest resolution in space $(0.25 \times 0.25)$ and time $(3 \mathrm{~h})$. In this regard, we used TRMM 3B42 V7 in this study for streamflow stimulation of the two study basins.

\section{Bias correction method for TRMM 3B42 products}

Although many TRMM rainfall products have been released since 1998, the year after TRMM satellite was launched, and researches about these products were carried out world-wide, the accuracy of satellite rainfall estimates has been questioned constantly due to a variety of error sources it is subject to, i.e., gaps in revisit times, poor direct relationship between remotely sensed signals and rainfall rate, and atmospheric effects that modify the radiation field. Bitew and Gebremichael (2011a, b) But TRMM rainfall products can reflect the spatial-temporal heterogeneity pattern of precipitation process and fill in the gap of data-sparse region, but with low precipitation accuracy. Since rain gauge measurements have relatively high precipitation accuracy at the gauge station point, complementing the TRMM satellite data with rain gauge measurements through a bias correction method and using it as an input to drive distributed hydrological model could enhance the runoff simulation precision. The two study areas are data-sparse basins; the available monthly precipitation data throughout a time span of 58 years (1951-2009) for Nam Khan River basin are provided by Luang Prabang meteorological station, and for Nam Like River basin the rain gauge data for the period 1995-2009 come from VangViang raingauge station only. Since high correlations exist between the TRMM 3B42 data and the rain gauge data for monthly resolution (Yang et al. 2009; Yuan et al. 2013; Meng et al. 2014), a monthly bias correction method, which is simple but effective, could be adopted to correct the TRMM 3B42 data (Arias-Hidalgo et al. 2013). Usually, the TRMM grid cell centres and the rain gauge location do not coincide. So the average monthly TRMM 3B42 data at the grid cells had to be interpolated to the rain gauge locations by using the inverse distance weighting method (IDW), a mostly used rainfall interpolating method developed by National Weather Service (Burrough et al. 1998). Thus, the average monthly precipitation values for the study period measured at each rain gauge location were compared against their TRMM interpolated counterparts to get the bias adjustment coefficients, respectively, which were later used to correct the TRMM monthly values.

A simple IDW function can be expressed as follows:

$Z=\left(\sum_{i=1}^{n} \frac{1}{\left({ }_{D i}\right)^{P}} Z_{i}\right) /\left(\sum_{i=1}^{n} \frac{1}{\left(D_{i}\right)^{P}}\right)$,

where $Z$ is the value of interpolated point, $Z i(i=1,2, \ldots$, $n)$ is the value of sample point $i, D i$ is the distance from the interpolated point to sample point $i$ (if $D i=0, Z=Z i$ ) and $P$ is a positive real number, called the power parameter. Here weight decreases as distance increases from the interpolated point to the sample point, and greater values of $P$ assign greater influence to values closest to the interpolated point, with the result of turning into a mosaic of tiles with nearly constant interpolated value for large values of $P$. In this article, $P$ was set to 2 .

\section{BTOPMC model description}

The physically based distributed hydrological model BTOPMC, developed from semi-distributed hydrological model TOPMODEL, has the characteristics of parsimonious calibrated parameters, relatively low requirement on inputs, being simple to operate and able to take advantage of satellite remote-sensing data, etc. The SCE-UA algorithm of Duan et al. (1994) was adopted to calibrate five essential parameters of BTOPMC; they are saturated soil transmissivity $T_{0}$, decay factor $m$, maximum storage capacity of the root zone $\mathrm{Sr}_{\max }$, saturated local saturation deficit $\mathrm{S}_{\mathrm{bar} 0}(k)$ of sub-basin $\mathrm{k}$ and Manning roughness coefficient $n$, the former four of which are for runoff generation and the other for flow routing. All these parameters have explicit physical meanings. BTOPMC divides the entire basin into sub-basins (lumped) that consist of a number of grid cells (distributed). Then, Runoff calculation is carried out for each grid cell by applying the assumptions and concepts of TOPMODEL to 
each sub-basin, and the Muskingum-Cunge (M-C) method (Fread 1993) was finally adopted to calculate flow routing.

Model performance is mainly evaluated by the volume ratio $\left(V_{\mathrm{r}}\right)$ and the Nash-Sutcliffe coefficient (NSCE; Nash and Sutcliffe (1970)). Volume ratio $V_{\mathrm{r}}$ is calculated as

$V_{\mathrm{r}}=\mathrm{TV}_{\mathrm{sim}} / \mathrm{TV}_{\mathrm{obs}}$,

where $\mathrm{TV}_{\text {sim }}$ is the total volume of simulated runoffs, and $\mathrm{TV}_{\mathrm{obs}}$ is the volume of observed runoffs. NSCE can be expressed as follows:

$$
\begin{aligned}
\mathrm{NSCE}= & {\left[1-\sum_{t=1}^{t=N}\left[Q_{\text {sim }}(t)-Q_{\mathrm{obs}}(t)\right]^{2} / \sum_{t=1}^{t=N}\left[Q_{o b s}(t)-Q_{a v}\right]^{2}\right] } \\
& \times 100 \%,
\end{aligned}
$$

where $N$ is the total number of time steps, $Q_{\text {sim }}(t)_{\mathrm{v}}$ is the simulated runoff at time step $t, Q_{\text {obs }}(t)$ is the observed runoff at time $t, Q_{\mathrm{av}}$ is the mean of observed runoffs over $\mathrm{t}$ time steps. NSCE is widely used to assessing the goodness of fit of hydrologic models, and the closer the model coefficient is to 1 , the more accurate the model is.

\section{Data preparation}

The data available for this study include the following: (1) a digital elevation model (DEM) provided by the Computer Network Information Center, Chinese Academy of Sciences (http://www.gscloud.cn/), at the spatial resolution of $30 \mathrm{~m}$; (2) land use/vegetation coverage data at a resolution of $1 \mathrm{~km}$ that were constructed from digitalizing and interpreting remote sensing images provided by International Geosphere Biosphere Programme, and soil data at a resolution of $1 \mathrm{~km}$ provided by Food and Agriculture Organization of the United Nations (FAO); (3) the monthly rain data from 2000 to 2004 of Luang Prabang meteorological station and VangViang rain gauge station, and the daily runoff data from 2000 to 2004 of Ban Pak Bak hydrological station, Ban Mout hydrological station, Kasi hydrological station and Hin Heup hydrological station (Fig. 1) were obtained from Laos Meteorological Administration. Moreover, the monthly evaporation data from 1980 to 2009 of Luang Prabang meteorological station and Muang Phonhong evaporation station (Fig. 1) for calculating mean monthly evaporation data and evapotranspiration were also derived from Laos Meteorological Administration. (4) TRMM 3B42 V7 rainfall data with high resolution in space $(0.25 \times 0.25)$ and time $(3 \mathrm{~h})$ downloaded freely from http://trmm.gsfc.nasa.gov/. The DEM data, land use/vegetation coverage data and soil data are re-sampled at the resolution of $300 \mathrm{~m}$ to match model calculation. The 3-hourly TRMM 3B42 V7 data were aggregated to daily resolution to drive BTOPMC.

\section{Results and discussions}

The TRMM 3B42 V7 daily precipitation and its bias-corrected data were, respectively, used to drive the distributed hydrological model to perform daily streamflow simulations at the Ban Pak Bak station, Ban Mout station located in Nam Khan River basin and Kasi station and Hin Heup station located in Nam Like River basin during the 5-year period from 2000 to 2004 so as to assess the feasibility of the TRMM precipitation on streamflow process simulation in Laos data-sparse basins. Nam Khan River basin and Nam Like River basin were both calibrated for the years from 2000 to 2002, but validated for the period from January, 2003 to August, 2004 (Nam Khan River basin) and from January, 2003 to November, 2004 (Nam Like River basin). The volume ratio $\left(V_{\mathrm{r}}\right)$ and NSCE served as the objective functions for parameter calibration, which was conducted using an effective and efficient SCE-UA global optimization algorithm. Besides, runoff depth and peak time were also adopted as statistic indicators to validate the effectiveness of streamflow simulation based on BTOPMC.

\section{Performance of non-corrected TRMM products for BTOPMC}

Figure 2 shows simulated streamflows forced by TRMM rainfall products at Ban Pak Bak, Ban Mout, Kasi and Hin Heup stations. The results indicate that daily streamflow process can be represented at large and good agreement exists between simulated daily streamflow process and TRMM daily areal mean precipitation series, except significant biases for both high-flow simulation (especially for peaks) and low-flow simulation.

The volume ratio $\left(V_{\mathrm{r}}\right)$ values vary from 0.54 to $1.80 . V_{\mathrm{r}}$ values at Kasi for calibration and validation period are 0.54 and 0.57 , respectively, which suggests a negative bias of stimulation. $V_{\mathrm{r}}$ values at Ban Pak Bak and Ban Mout for calibration period are 1.64, 1.80, respectively, which suggests a positive bias of stimulation (Table 1). On the one hand, TRMM rainfall products are derived from nearground precipitation information, which contain evaporation loss during precipitation process, and thus might be the reason for the overestimation of total simulated streamflow volume. On the other hand, since the study basins are located in mountainous region of north Laos characterized by convective rainfall and orographic rainfall, where satellite rainfall amout is usually underestimated, and it might be the cause of underestimation of simulated streamflow peaks. Beyond these, while the spatial resolution of TRMM rainfall products is $0.25 \times 0.25$, the drainage area of Kasi station is only $374 \mathrm{~km}^{2}$, which leads to few TRMM grids over the controlled catchment area of 

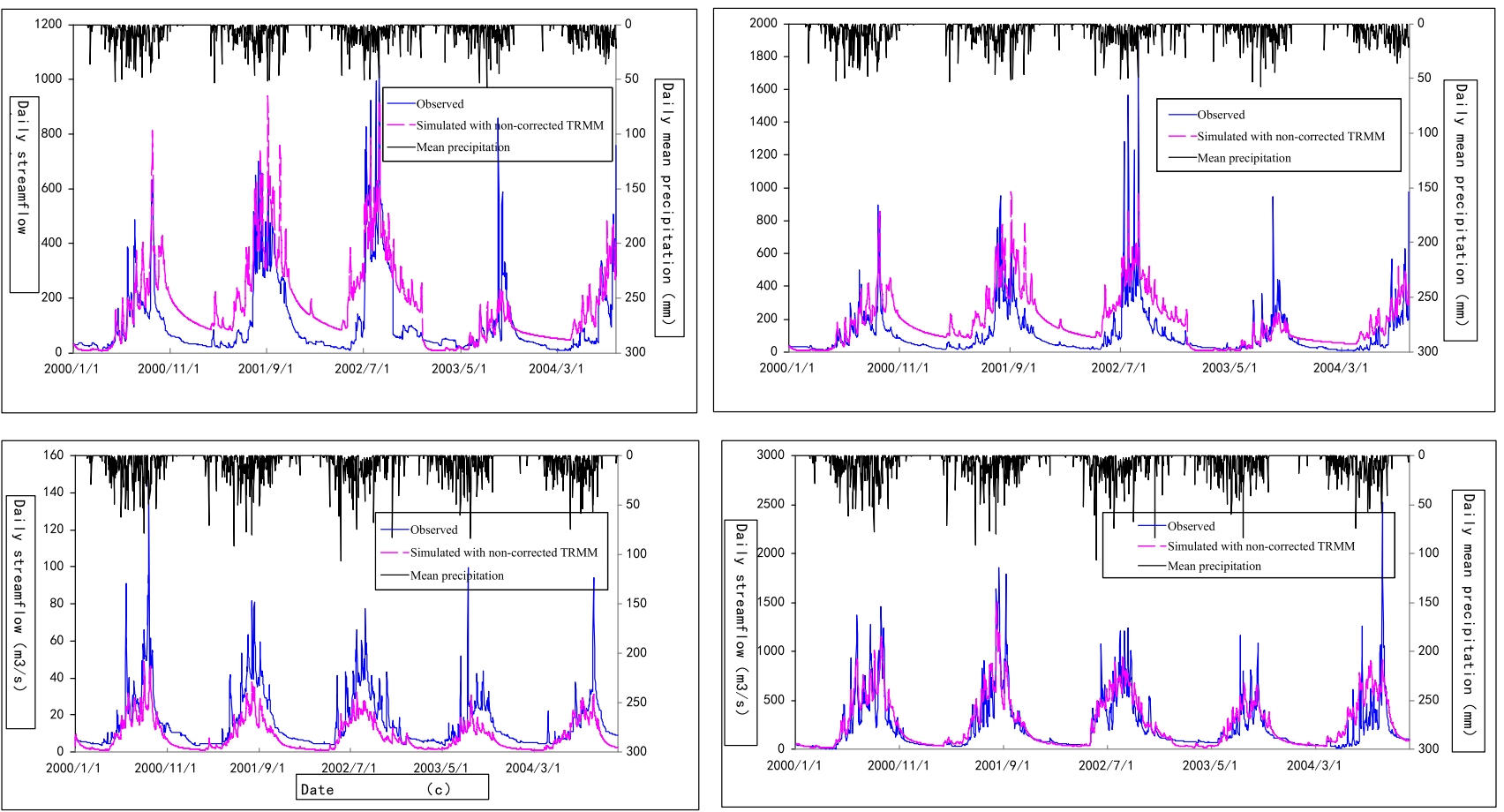

Fig. 2 Hydrographs of daily stream flow with TRMM precipitation for model calibration and validation (2000-2004) at a Ban Pak Bak station, b Ban Mout station, c Kasi station, d Hin Heup station

Kasi. The objective function in parameter optimization of BTOPMC is designed as follows:

$F=1-\sum_{\mathrm{i}=1}^{N} w_{i} \mathrm{NSCE}_{i}$,

where $N$ denotes the total number of calibration sites in study basin, $\mathrm{w}$ is the weighting factor and the sum of $w_{i}$ equals 1.0; NSCE denotes the Nash-Sutcliffe coefficient.

Due to optimized parameter values in Nam Like River basin calculated by daily hydro-climatic data from two stations, namely $w_{1}$ and $w_{2}$ set to 0.5 , respectively, the simulated streamflow peaks at Hin Heup influenced by Kasi were also underestimated.

Whether for calibration period or for validation period, NSCE values vary between 25.65 and $83.07 \%$ (Table 1), which is not very satisfactory. Owing to lack of observed daily rainfall data which are used to drive BTOPMC, it is difficult to determine the predominant influence of the unwanted simulation results. A more possible explanation for the results may be the uncertainty of TRMM rainfall. Although the NSCE value for Hin Heup station reaches the highest $83.07 \%$ for the calibration period, it decreases to $44.47 \%$ for the validation period (Table 1). From Sect. 2.1, we can see that the terrain of Nam Like River basin is more complicated than Nam Khan River basin, which will likely reduce hydrological model reliability. But based on the presented results at Hin Heup station, it is more likely that the model can provide a sound basis for applicability of TRMM rainfall in Nam Like River basin. An intercomparison of NSCE values obtained both from calibrating and validating period indicate that the calibrated parameters perform better in Nam Khan River basin than that in Nam Like River basin.

For peak representation simulation, we employed ratio value $\mathrm{R}$ to evaluate its performance. Ratio value $\mathrm{R}$ can be expressed as follows:

$R=N / M$,

where $R$ is the ratio value, $N$ is the number of correctly simulated peaks above a given peak flow $Q\left(\mathrm{~m}^{3} / \mathrm{s}\right)$ and $M$ is the total number of observed peak flows above a given peak flow $Q\left(\mathrm{~m}^{3} / \mathrm{s}\right)$.

For Nam Khan River basin, when $Q$ is $200 \mathrm{~m}^{3} / \mathrm{s}, R$ for Ban Pak Bak and Ban Mout are 87.94 and $86.21 \%$, respectively; when $Q$ is $400 \mathrm{~m}^{3} / \mathrm{s}, R$ for Ban Pak Bak and Ban Mout are 84.44 and $87.18 \%$, respectively. For Nam Like River basin, when $Q$ is 20 or $40 \mathrm{~m}^{3} / \mathrm{s}, R$ for Kasi is 40.33 or $4.44 \%$; when $Q$ is 500 or $700 \mathrm{~m}^{3} / \mathrm{s}, R$ for Hin Heup is 86.78 or $59.00 \%$. These statistical summaries suggest that peak representation simulation performs well, except at Kasi.

\section{Performance of bias-corrected TRMM products for BTOPMC}

Figure 3 shows simulated and observed streamflow forced by bias-corrected TRMM rainfall products at Ban Pak Bak, 
Table 1 The statistical indicators of daily streamflow simulations at the four stations

\begin{tabular}{|c|c|c|c|c|c|c|c|c|}
\hline \multirow[t]{3}{*}{ Indicator } & \multicolumn{8}{|c|}{ Types of precipitation station } \\
\hline & \multicolumn{2}{|l|}{ Raw TRMM } & \multicolumn{2}{|c|}{ Bias-corrected TRMM } & \multicolumn{2}{|c|}{ Raw TRMM } & \multicolumn{2}{|c|}{ Bias-corrected TRMM } \\
\hline & Ban Pak Bak & Ban Mout & Ban Pak Bak & Ban Mout & Kasi & Hin Heup & Kasi & Hin Heup \\
\hline \multicolumn{9}{|l|}{ NSCE $(\%)$} \\
\hline Calibration & 39.77 & 25.65 & 53.89 & 40.29 & 39.75 & 83.07 & 32.71 & 78.35 \\
\hline Validation & 32.7 & 51.2 & 39.14 & 55.43 & 26.92 & 44.47 & 28.92 & 44.43 \\
\hline \multicolumn{9}{|c|}{ Depth of total runoff (m) } \\
\hline \multicolumn{9}{|l|}{ Simulated } \\
\hline Calibration & 3.57 & 3.58 & 2.83 & 2.84 & 6.04 & 5.95 & 5.89 & 5.81 \\
\hline Validation & 0.86 & 0.86 & 0.8 & 0.8 & 2.94 & 3.02 & 2.99 & 3.08 \\
\hline \multicolumn{9}{|l|}{ Observed } \\
\hline Calibration & 2.19 & 1.99 & 2.19 & 1.99 & 11.1 & 5.54 & 11.1 & 5.54 \\
\hline Validation & 0.71 & 0.68 & 0.71 & 0.68 & 5.17 & 2.48 & 5.17 & 2.48 \\
\hline \multicolumn{9}{|l|}{$V_{\mathrm{r}}$} \\
\hline Calibration & 1.64 & 1.8 & 1.3 & 1.24 & 0.54 & 1.08 & 0.53 & 1.05 \\
\hline Validation & 1.22 & 1.26 & 1.13 & 1.11 & 0.57 & 1.22 & 0.58 & 1.24 \\
\hline \multicolumn{9}{|c|}{ Mean precipitation (m) } \\
\hline Calibration & 5.34 & 5.28 & 4.63 & 4.62 & 7.17 & 6.73 & 6.91 & 6.4 \\
\hline Validation & 2.67 & 2.67 & 2.49 & 2.47 & 3.86 & 4.03 & 3.66 & 3.83 \\
\hline \multicolumn{9}{|l|}{ Peak time (date) } \\
\hline \multicolumn{9}{|l|}{ Simulated } \\
\hline Calibration & $2001 / 9 / 3$ & $2001 / 9 / 3$ & $2001 / 9 / 3$ & $2001 / 9 / 3$ & $2000 / 8 / 17$ & $2001 / 8 / 10$ & $2000 / 9 / 6$ & $2000 / 9 / 6$ \\
\hline Validation & $2004 / 8 / 2$ & $2004 / 8 / 2$ & $2004 / 8 / 1$ & $2004 / 8 / 2$ & $2004 / 9 / 11$ & $2004 / 9 / 12$ & $2003 / 8 / 2$ & $2004 / 9 / 11$ \\
\hline \multicolumn{9}{|l|}{ Observed } \\
\hline Calibration & $2002 / 8 / 17$ & $2002 / 8 / 18$ & $2002 / 8 / 17$ & $2002 / 8 / 18$ & $2000 / 9 / 1$ & $2001 / 8 / 17$ & $2000 / 9 / 1$ & $2001 / 8 / 17$ \\
\hline Validation & $2003 / 8 / 26$ & $2004 / 8 / 31$ & $2003 / 8 / 26$ & $2004 / 8 / 31$ & $2004 / 9 / 11$ & $2004 / 9 / 11$ & 2004/9/11 & $2004 / 9 / 11$ \\
\hline
\end{tabular}

Ban Mout, Kasi and Hin Heup stations. The results also indicate that daily streamflow process can be represented at large and that good agreement exists between simulated daily streamflow process and daily TRMM precipitation series. The volume ratio $\left(V_{\mathrm{r}}\right)$ values vary from 0.53 to 1.30 . $V_{\mathrm{r}}$ values at Kasi and Hin Heup for calibration and validation period remain almost the same, while $V_{\mathrm{r}}$ values at Ban Pak Bak and Ban Mout for calibration period are 1.30 and 1.24, which suggests an apparent improvement (Table 1).

NSCE values vary from 28.92 to $78.35 \%$ (Table 1). While NSCE values for Nam Khan River basin increased by employing bias-corrected TRMM to drive BTOPMC for streamflow stimulation, NSCE values for Nam Like River basin did not improve. In virtue of the great distances between anchor point (VangViang station) and Kasi, Hin Heup stations, the simple bias-correction method cannot be adequately accurate and thus undermines the correction effects. Judged from NSCE values, the calibrated parameters perform better at Nam Khan River basin than at Nam Like River basin.

As to peak representation simulation, for Nam Khan River basin, when $Q$ is $200 \mathrm{~m}^{3} / \mathrm{s}, R$ values for Ban Pak Bak and Ban Mout are 81.56, $78.16 \%$, respectively; when $Q$ is $400 \mathrm{~m}^{3} / \mathrm{s}, R$ values for Ban Pak Bak and Ban Mout are $48.89,57.69 \%$, respectively. Compared to simulation results derived from non-corrected TRMM rainfall products at Nam Khan River basin, while NSCE values increased a little bit, $\mathrm{R}$ values decreased here, which corresponds to the conclusion of Harris et al. (2007) in satellite-based flood modelling: The bias adjustment of satellite rainfall data can improve application in flood prediction to some extent with the trade-off of more false alarms in peak flow stimulation. For Nam Like River basin, when Q is 20 or $40 \mathrm{~m}^{3} / \mathrm{s}, R$ for Kasi is 32.64 or $5.18 \%$; when $Q$ is 500 or $700 \mathrm{~m}^{3} / \mathrm{s}, R$ for Hin Heup is 83.47 or $44.60 \%$. These statistical summaries also suggest that peak representation simulation performs well except at Kasi. Although BTOPMC model was driven by bias-corrected rainfall products, the simulation results for both high-flow (especially for peaks) and low-flow are still poor (Fig. 3). Figure 4 illustrates graphical comparisons of observed and simulated daily hydrographs with the uncorrected and corrected TRMM data. After all, the performance of streamflow stimulation has been improved for 

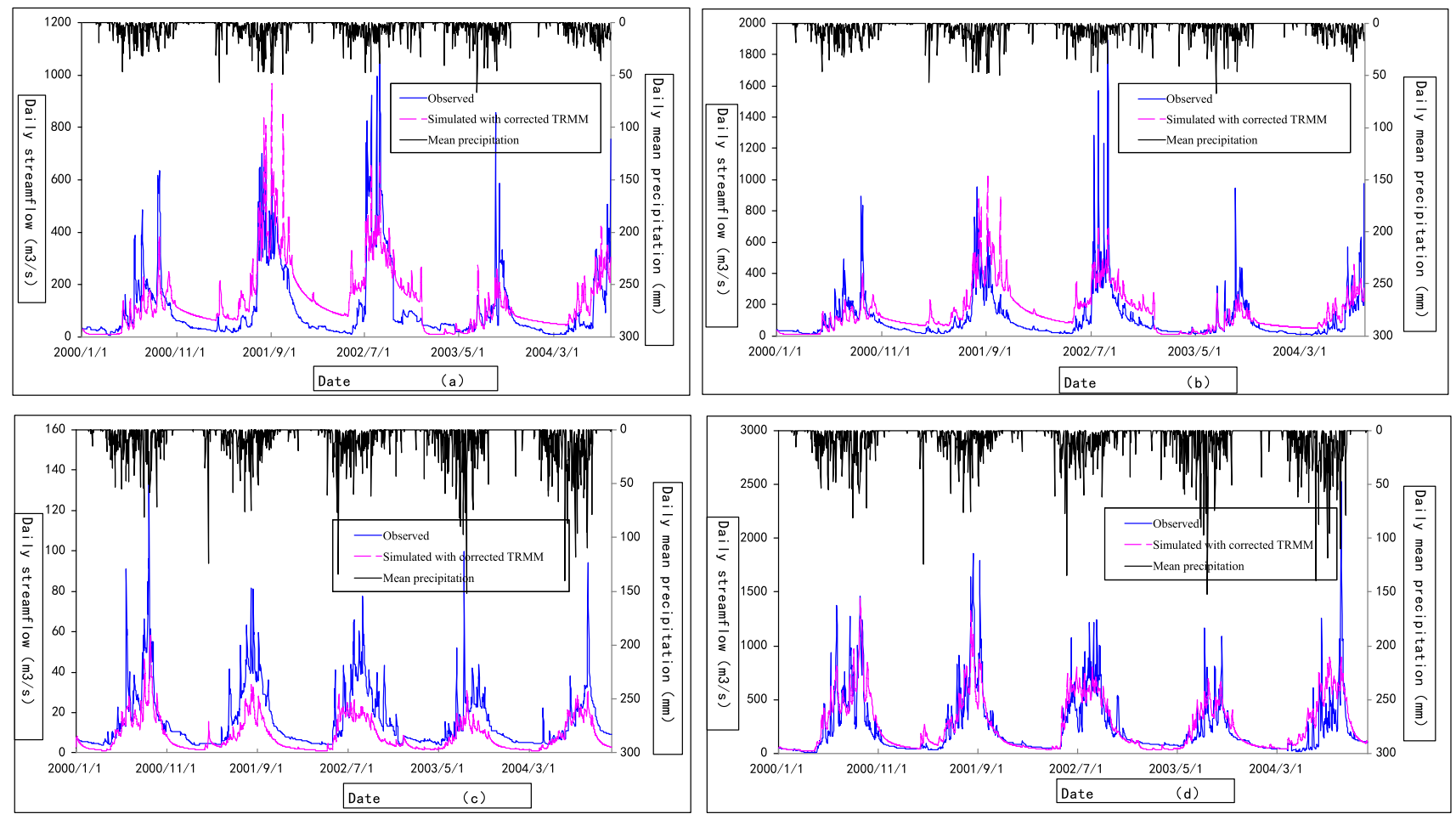

Fig. 3 Hydrographs of daily stream flow with bias corrected TRMM precipitation for model calibration and validation (2000-2004) at a Ban Pak Bak station, b Ban Mout station, $\mathbf{c}$ Kasi station, d Hin Heup station
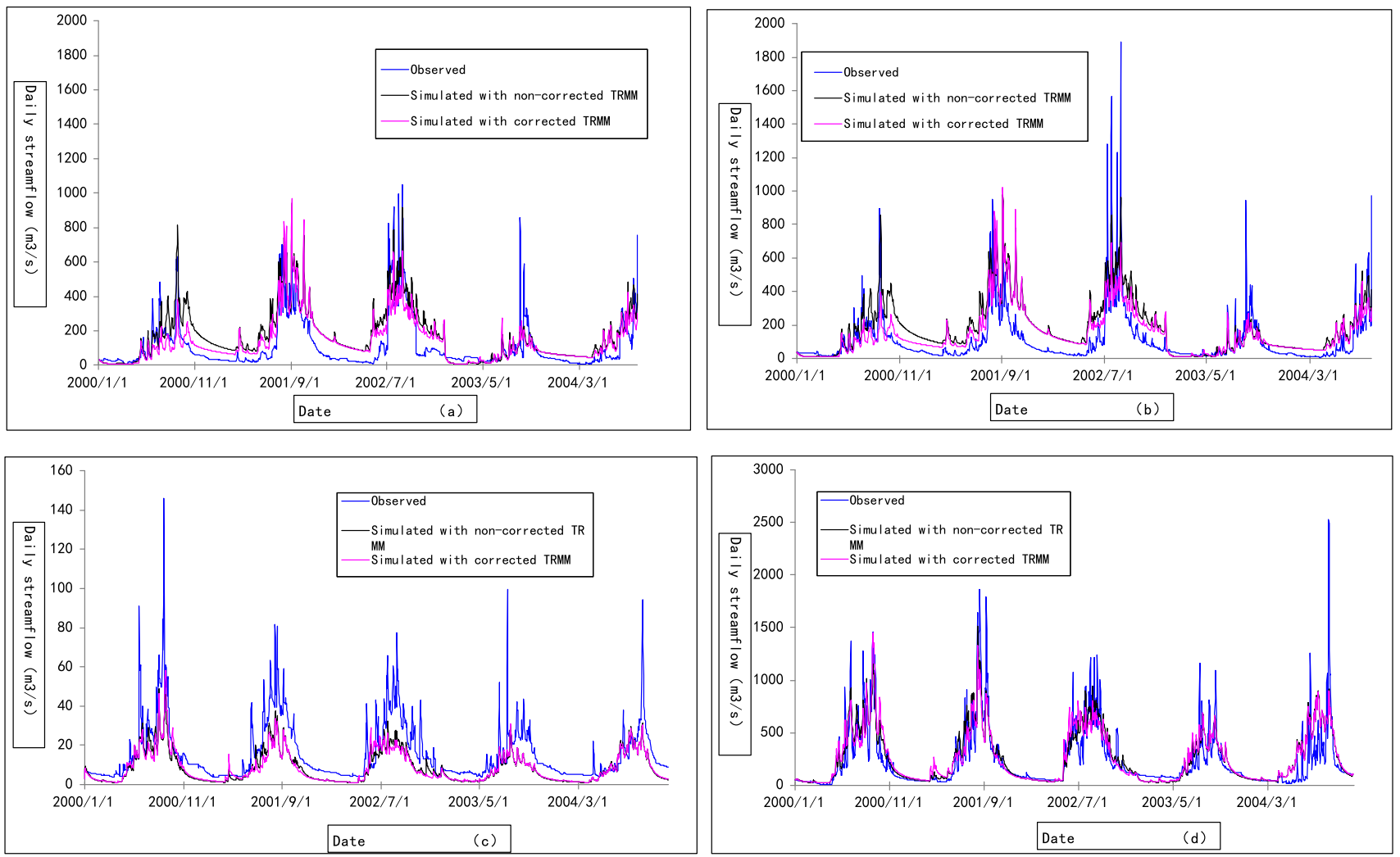

Fig. 4 Comparison of the observed and simulated daily hydrographs with different types of precipitation at a Ban Pak Bak station, b Ban Mout station, c Kasi station, d Hin Heup station 
Nam Khan River basin by taking advantage of bias-corrected TRMM rainfall data, especially during non-flood season, while for Nam Like River basin the results did not improve.

\section{Conclusions}

Whether driven by original or bias-corrected TRMM rainfall data, the simulated streamflow can represent daily flow at large at Ban Pak Bak, Ban Mout, Kasi and Hin Heup stations, except for the underestimation of high-flow and low-flow. Compared to raw TRMM rainfall data, the bias adjustment of TRMM rainfall data can improve application in flood prediction to some extent, but with the trade-off of more false alarms in peak flow. The NSCE and $V_{\mathrm{r}}$ values indicate that the calibrated parameters perform better at Nam Khan River basin than at Nam Like River basin. Overall, this study demonstrates the feasibility of TRMM rainfall data (whether original or bias-corrected) which can reflect the spatial distribution of rainfall in streamflow stimulation at data-sparse area of Laos, although the daily flow simulation results are not that satisfactory. Also the TRMM data provide a potential alternative source of forcing data for hydrological models in sparse regions where conventional in situ precipitation measurements are not readily available.

Since the Global Precipitation Climatology Center $1 \times 1$ monthly monitoring product has already been used to adjust TMPA products (Huffman et al. 2007) and the rain gauge stations are sparsely located in the study area, the simple bias-correction method presented in the article is not that effective for improving streamflow simulation accuracy. It is necessary to develop further correction algorithms, data integration and downscaling for satellite precipitation in terms of both the accuracy and spatiotemporal resolutions of rainfall estimates (Tobin and Bennett 2010; Meng et al. 2014). But, the results demonstrate the potential of combining TRMM rainfall data with rain gauge data to drive distributed hydrological model for rainfall-runoff stimulation in data-sparse area. What is more, the uncertainty contained in each input would contribute to undermine the simulation results and hence how to weaken the uncertainty of distributed hydrological model remains a thorny issue to be resolved.

Acknowledgments This study was supported by the National Natural Science Foundation of China (Project No. 50979062); the International S\&T Cooperation Projects, the Ministry of Science and Technology of P. R. China (No. 2012DFG21780); the S\&T Project of Sichuan Environmental Protection (No. 11HBT-01); the National Basic Search Fund Project of Sichuan University (No. 2010SCU22005); the Development Project of Sichuan Province's Flash Flood Real-Time Prediction System and the development and application Project of the integrated storm-flood simulation and prediction system of flood disaster mountain basin in Sichuan Province.

Open Access This article is distributed under the terms of the Creative Commons Attribution 4.0 International License (http:// creativecommons.org/licenses/by/4.0/), which permits unrestricted use, distribution, and reproduction in any medium, provided you give appropriate credit to the original author(s) and the source, provide a link to the Creative Commons license, and indicate if changes were made.

\section{References}

Ao T (2001) Development of a distributed hydrological model for large river basins and its application to Southeast Asian rivers, $\mathrm{PhD}$ thesis, University of Yamanashi, Kofu, Japan

Ao $\mathrm{T}$ et al (2006) Relating BTOPMC model parameters to physical features of MOPEX basins. J Hydrol 320(1):84-102

Arias-Hidalgo $\mathrm{M}$ et al (2013) Experiences in using the TMPA-3B42R satellite data to complement rain gauge measurements in the Ecuadorian coastal foothills. Hydrol Earth Syst Sci 17(7):2905-2915

Artan G et al (2007) Adequacy of satellite derived rainfall data for stream flow modelling. Nat Hazards 43(2):167-185

Beven K et al (1995) Topmodel. In: Singh VP (ed) Computer models of watershed hydrology, Water Resources Publications, Colorado, pp 627-668

Bitew MM, Gebremichael M (2011a) Assessment of satellite rainfall products for streamflow simulation in medium watersheds of the Ethiopian highlands. Hydrol Earth Syst Sci 15(4):1147-1155

Bitew MM, Gebremichael M (2011b) Evaluation of satellite rainfall products through hydrologic simulation in a fully distributed hydrologic model. Water Resour Res 47(6):W06526

Burrough PA et al (1998) Principles of geographical information systems. Oxford University Press, Oxford

Collischonn B et al (2008) Daily hydrological modelling in the Amazon basin using TRMM rainfall estimates. J Hydrol 360(1-4):207-216

Cunge JA (1969) On the subject of a flood propagation computation method (Musklngum method). J Hydraul Res 7(2):205-230

Duan Q et al (1994) Optimal use of the SCE-UA global optimization method for calibrating watershed models. J Hydrol 158(3):265-284

Fread D (1993) Flow routing. In: Maidment DR (ed) Handbook of hydrology, McGraw-Hill, New York, pp 10.1-10.36

$\mathrm{Gu} \mathrm{H}$ et al (2010) Hydrological assessment of TRMM rainfall data over Yangtze River Basin. Water Sci Eng 3(4):418-430

Habib E et al (2009) Evaluation of TMPA satellite-based research and real-time rainfall estimates during six tropical-related heavy rainfall events over Louisiana, USA. Atmos Res 94(3):373-388

Harris A et al (2007) Satellite-based flood modelling using TRMMbased rainfall products. Sensors 7(12):3416-3427

Hapuarachchi HAP et al (2004) Eliminating uncertainty associated with classifying soil types in distributed hydrologic modelling, Proc. of 2nd APHW conference, Singapore, pp 592-600

Hapuarachchi HAP et al (2007) Importance of rainfall measurements for the flood forecasting of the Mekong River Basin, Research Report, Public Works Research Institute, Japan

Hong Y et al (2007) A first approach to global runoff simulation using satellite rainfall estimation. Water Resour Res 43(8):W08502

Huffman GJ et al (2007) The TRMM multisatellite precipitation analysis (TMPA): quasi-global, multiyear, combined-sensor

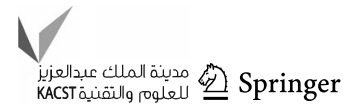


precipitation estimates at fine scales. $\mathrm{J}$ Hydrometeorol $8(1): 38-55$

Jia $S$ et al (2011) A statistical spatial downscaling algorithm of TRMM precipitation based on NDVI and DEM in the Qaidam Basin of China. Remote Sens Environ 115(12):3069-3079

Jiang S et al (2012) Comprehensive evaluation of multi-satellite precipitation products with a dense rain gauge network and optimally merging their simulated hydrological flows using the Bayesian model averaging method. J Hydrol 452-453:213-225

Joyce RJ et al (2004) CMORPH: a method that produces global precipitation estimates from passive microwave and infrared data at high spatial and temporal resolution. J Hydrometeorol 5(3):487-503

Kim JP et al (2013) Application of high resolution multi-satellite precipitation products and a distributed hydrological modelling for daily runoff simulation. Korean $J$ Remote Sens 29(2):263-274

Li L et al (2013) Comparison of the global TRMM and WFD precipitation datasets in driving a large-scale hydrological model in southern Africa. Hydrol Res 44(5):770

Liu Y et al (2011) Satellite retrieval of precipitation: an overview. Adv Earth Sci 26(11):1161-1172

Mao H (2008) TRMM rainfall applied in flow prediction of LSHM in upper Hanjiang River Basin. Express Water Resour Hydropower Inf 29(8):22-26

Meng J et al (2014) Suitability of TRMM satellite rainfall in driving a distributed hydrological model in the source region of Yellow River. J Hydrol 509:320-332

Nash J, Sutcliffe J (1970) River flow forecasting through conceptual models part I-A discussion of principles. J Hydrol 10(3):282-290

Sawunyama T, Hughes D (2008) Application of satellite-derived rainfall estimates to extend water resource simulation modelling in South Africa. Water SA 34(1):1-9

Scheel M et al (2011) Evaluation of TRMM Multi-satellite Precipitation Analysis (TMPA) performance in the Central Andes region and its dependency on spatial and temporal resolution. Hydrol Earth Syst Sci 15(8):2649-2663
Sivapalan M et al (2003) IAHS Decade on predictions in ungauged basins (PUB), 2003-2012: shaping an exciting future for the hydrological sciences. Hydrol Sci J 48(6):857-880

Sorooshian S et al (2000) Evaluation of PERSIANN system satellitebased estimates of tropical rainfall. Bull Am Meteorol Soc 81(9):2035-2046

Sorooshian S et al (2005) Water and energy cycles: investigating the links. World Meteorological Organ Bull 54(2):58-64

Stisen S, Sandholt I (2010) Evaluation of remote-sensing-based rainfall products through predictive capability in hydrological runoff modelling. Hydrol Process 24(7):879-891

Su F et al (2008) Evaluation of TRMM multisatellite precipitation analysis (TMPA) and Its utility in hydrologic prediction in the La Plata Basin. J Hydrometeorol 9(4):622-640

Takeuchi K et al (1999) Introduction of block-wise use of TOPMODEL and Muskingum-Cunge method for the hydroenvironmental simulation of a large ungauged basin. Hydrol Sci J 44(4):633-646

Tobin KJ, Bennett ME (2010) Adjusting satellite precipitation data to facilitate hydrologic modelling. J Hydrometeorol 11(4):966-978

Xue X et al (2013) Statistical and hydrological evaluation of TRMMbased multi-satellite precipitation analysis over the Wangchu Basin of Bhutan: are the latest satellite precipitation products 3B42V7 ready for use in ungauged basins? J Hydrol 499:91-99

Yang C et al (2009) Study on watershed hydrologic processes using TRMM satellite precipitation radar products. Adv Water Sci 20(4):461-466

Yong B et al (2010) Hydrologic evaluation of Multisatellite Precipitation Analysis standard precipitation products in basins beyond its inclined latitude band: a case study in Laohahe basin, China. Water Resour Res 46(7):W07542

Yong B et al (2012) Assessment of evolving TRMM-based multisatellite real-time precipitation estimation methods and their impacts on hydrologic prediction in a high latitude basin. J Geophys Res Atmos (1984-2012) 117(D9)

Yuan F et al (2013) Streamflow simulation in the Upper Ganjiang River Basin using the TRMM multi-satellite precipitation data. J Tianjin Univ (Sci Technol) 46(7):611-616 